\title{
Erratum: Cooper pair splitting in parallel quantum dot Josephson junctions
}

\author{
R.S. Deacon, A. Oiwa, J. Sailer, S. Baba, Y. Kanai, K. Shibata, K. Hirakawa \& S. Tarucha
}

Nature Communications 6:7446 doi: 10.1038/ncomms8446 (2015); Published 1 Jul 2015; Updated 14 Dec 2015

The financial support for this Article was not fully acknowledged. The Acknowledgements should have included the following:

ST acknowledges financial support from Grant-in-Aid Research S No. 26220710.

\footnotetext{
(c) (i) This work is licensed under a Creative Commons Attribution 4.0 International License. The images or other third party material in this article are included in the article's Creative Commons license, unless indicated otherwise in the credit line; if the material is not included under the Creative Commons license, users will need to obtain permission from the license holder to reproduce the material. To view a copy of this license, visit http://creativecommons.org/licenses/by/4.0/
} 